\title{
THE EFFECT OF VERMICOMPOST AND NPK FERTILIZER ON TOMATO (Solanum lycopersicum) GROWTH
}

\author{
Ahmad Raksun*, Moh. Liwa Ilhamdi, I Wayan Merta, and I Gde Mertha \\ Biology Education Deparment, Faculty of Teacher Training and Education, University of Mataram, \\ Mataram, Indonesia \\ *Email: ahmadunram@unram.ac.id
}

Accepted: November, 20 2021. Approved: November, 30 2021. Published: November, 302021

\begin{abstract}
Tomato is a plant of solanaceae family, has short stems, and grows well in tropical climates. Tomatoes have vegetative and generative growth phases. The availability of nutrients largely determines the vegetative growth phase. The purpose of the study is to determine: (1) the effect of vermicompost on tomato growth, (2) the effect of NPK fertilizer treatment on tomato growth, (3) the interaction effect of vermicompost and NPK fertilizer on tomato growth. The research was conducted using experimental methods. The research was carried out from April to July 2021. The research design was a $4 \times 5$ complete random factorial design with three repetitions. NPK fertilizer consisted of 4 levels of treatment doses, while vermicompost consisted of 5 levels of treatment doses. The research finding shows that the application of NPK fertilizer of 0.8 grams per plant significantly affected stem diameter, the number of compound leaves, leaf length, and stem height of tomatoes. Treatment of vermicompost of $1.8 \mathrm{~kg}$ of vermicompost resulted in the best stem diameter, number of compound leaves, leaf length, and stem height. The combination of vermicompost and NPK fertilizer had no significant effect on stem diameter, the number of compound leaves, leaf length, and stem height of tomatoes.
\end{abstract}

Keywords: Vermicompost and NPK fertilizer, tomato growth

\section{INTRODUCTION}

Tomato (Solanum lycopersicum) is a plant of solonaceae family, a not woody shrub plant with short stems which contains a lot of water. Tomatoes have two growth phases: the vegetative and generative phases. The vegetative phase starts when the seeds begin to germinate until the plant starts to flower. The vegetative phase lasts about 45 to 55 days [1]. Tomato is a vegetable commodity that is widely cultivated by Indonesian farming communities. Tomatoes have many benefits. It can also be used as raw materials for medicines, cosmetics, herbs, sauces, and beverages. As a food ingredient, tomatoes have sufficient nutrient content. Tomatoes contain carbohydrates, protein, fat, fiber, and minerals such as calcium, phosphorus, iron, sodium, and potassium. Tomatoes also have vitamin $\mathrm{A}$ and vitamin B [2].

At present, Indonesian farming communities, farming communities on the island of Lombok to be particular, utilize chemical fertilizers such as urea and NPK fertilizers in plant cultivation. Long-term utilization of chemical fertilizers can initiate the degradation of agricultural land functions [3]. The simultaneous utilization of chemical fertilizers and synthetic pesticides for a long time will cause the organic matter content in the soil to decrease and the soil structure to become hard to cultivate naturally [4]. It is necessary to combine the use of chemical fertilizers and organic fertilizers. One of the organic fertilizers that can be used is vermicompost.

Vermicompost is earthworm droppings, namely soil used for worm maintenance, a by-product of earthworm cultivation. Vermicompost is inorganic fertilizer suitable for plant growth because it can increase soil fertility [5]. Vermicompost is finetextured earthworm excrement. The excrement results from processed organic materials and some essential mineral elements from the soil that are eaten by worms. Vermicompost benefits plants, including fertilizing and loosening the soil to be suitable as a planting medium, stimulating root, stem, and leaf growth, stimulating flower growth, accelerating harvest, and increasing productivity [6].

The utilization of vermicompost as organic fertilizer can increase plant growth. Giving vermicompost can increase the length and weight of the cob per plot production and accelerate the harvesting period of corn plants. The interaction of vermicompost and NPK has a real effect on the length and weight of the cob, per plot production, acceleration of the harvest period [7]. The 60-gram vermicompost fertilizer treatment affected the height of the mustard plant with a value of $18.6 \mathrm{~cm}$. Wet plant weighed 10.3 gram, plant dry weighed 1.3 gram, and root dry weighed 0.4 gram [8]. The vermicompost fertilizer treatment significantly affected the number of fruits per plant and the height 
of okra and shallot plants grown with an intercropping system [9].

Based on the explanations above, the study about the effect of Vermicompost and NPK on tomatoes' (Solanum lypcopersicum) growth was carried out. The purpose of the study is to determine: 1) the effect of Vermicompost treatment on tomatoes growth, 2) the effect of NPK fertilizer on tomatoes growth, 3) interaction effect between vermicompost and NPK fertilizer on tomatoes growth. The study was held from April to July of 2021.

\section{RESEARCH METHODS}

The study is an experimental study with a complete random factorial with three repetitions. The first factor is a treatment of NPK fertilizers consist 4 treatments, namely: $\mathrm{A}_{0}=0$ gram of NPK fertilizer; $\mathrm{A}_{1}=0.8$ gram of NPK fertilizer, and $\mathrm{A}_{3}=1.2$ gram of NPK fertilizer. The treatment of NPK fertilizer was carried out two times, namely when the tomato plants were 15 days old and 30 days after planting. Treatment of NPK fertilizer was done by dissolving NPK fertilizer in 0.5 liters of water. The second factor is the treatment of vermicompost. It consists of 5 levels of treatment, namely: $\mathrm{K}_{0}=$ treatment of $0 \mathrm{~kg}$ of vermicompost, $\mathrm{K}_{1}=$ treatment of $0.6 \mathrm{~kg}$ of vermicompost, $\mathrm{K}_{2}=$ treatment of $1.2 \mathrm{~kg}$ of vermicompost, $\mathrm{K}_{3}=$ treatment of $1.8 \mathrm{~kg}$ of vermicompost, $\mathrm{K}_{4}=$ treatment of $2.4 \mathrm{~kg}$ of vermicompost fertilizer. The vermicompost fertilizer treatment was carried out 10 days before planting by mixing the vermicompost with topsoil. Each treatment was carried out on one $\mathrm{m}^{2}$ of agricultural land.

The materials used were: vermicompost fertilizer, tomato seeds purchased at UD Sinta Mataram, well water, seed poly bags, the topsoil of paddy field soil, NPK pearl fertilizer, paranet net, transparent paper, woven bamboo fence, rope, and bamboo stake. The tools used were: hand sprayers, water pump machines, nylon sacks, sickles, hoes, machetes, plastic buckets, meter measuring tools, scales, measuring cups, and writing utensils. The research was carried out in 8 stages: (1) preparation of tools and materials (2) seedling of tomatoes using soil media (3) procurement of vermicompost fertilizer, (4) dismantling the land and making beds with a length $\mathrm{x}$ width of $15 \mathrm{~m} \mathrm{x} 1 \mathrm{~m}$, (4) application of vermicompost at the research site 10 days after planting, (5) planting tomato seedlings, (6) irrigating experimental land once in 10 days, (7) eradicating plant pests and diseases, (8) collecting research data, (9) analyzing research data. Growth parameters measured were stem diameter, number of compound leaves, leaf length, and height of tomato plants. Research data were analyzed by analysis of variance [10-11].

\section{RESULT AND DISCUSSION Stem Diameter}

The results of research on the effect of vermicompost and NPK on tomato growth showed differences in stem diameter, leaf blade length, number of compound leaves, and plant height in each treatment combination. Generally, all the tomato plant growth parameters increased with increasing doses of vermicompost and NPK fertilizers. The data from the measurement of tomato stem diameter is presented in Table 1. Based on Table 1, the highest tomato plant stem diameter was $18 \mathrm{~mm}$, obtained from a combination of 0.8 grams of NPK fertilizer and $1.8 \mathrm{~kg}$ of vermicompost fertilizer. The lowest stem diameter of tomato plants was $12 \mathrm{~mm}$, found in tomato plants without NPK fertilizer and vermicompost fertilizer.

Table 1. The diameter data of Tomato due to the treatment of NPK and Vermicompost fertilizers.

\begin{tabular}{cccc}
\hline Combination & $\begin{array}{c}\text { Stem Diameter } \\
(\mathrm{mm})\end{array}$ & Combination & $\begin{array}{c}\text { Stem diameter } \\
(\mathrm{mm})\end{array}$ \\
\hline $\mathrm{A} 0 \mathrm{~K} 0$ & 12 & $\mathrm{~A} 2 \mathrm{~K} 0$ & 14 \\
$\mathrm{~A} 0 \mathrm{~K} 1$ & 14 & $\mathrm{~A} 2 \mathrm{~K}_{1}$ & 15 \\
$\mathrm{~A} 0 \mathrm{~K} 2$ & 15 & $\mathrm{~A} 2 \mathrm{~K} 2$ & 16 \\
$\mathrm{~A} 0 \mathrm{~K} 3$ & 16 & $\mathrm{~A} 2 \mathrm{~K} 3$ & 18 \\
$\mathrm{~A} 0 \mathrm{~K} 4$ & 15 & $\mathrm{~A} 2 \mathrm{~K} 4$ & 16 \\
$\mathrm{~A} 1 \mathrm{~K} 0$ & 12 & $\mathrm{~A} 3 \mathrm{~K} 0$ & 14 \\
$\mathrm{~A} 1 \mathrm{~K}_{1}$ & 14 & $\mathrm{~A} 3 \mathrm{~K}_{1}$ & 15 \\
$\mathrm{~A} 1 \mathrm{~K} 2$ & 16 & $\mathrm{~A} 3 \mathrm{~K}_{2}$ & 15 \\
$\mathrm{~A} 1 \mathrm{~K} 3$ & 17 & $\mathrm{~A} 3 \mathrm{~K} 3$ & 16 \\
$\mathrm{~A} 1 \mathrm{~K} 4$ & 16 & $\mathrm{~A} 3 \mathrm{~K} 4$ & 16 \\
\hline
\end{tabular}


The analysis of diversity showed that the treatment of vermicompost with different doses significantly affected the stem diameter of tomato plants. The application of NPK fertilizer resulted in significantly different tomato stem diameters, with the highest stem diameter of $18 \mathrm{~mm}$ obtained at the treatment of 0.6 grams of NPK fertilizer per plant. The interaction of vermicompost and NPK fertilizer had no significant effect on tomato stem diameter. The presence of macro and micronutrients in vermicompost fertilizer is assumed to cause the increase in stem diameter of tomato plants. The availability of nutrients is very decisive for plant growth. The vermicompost contains complete nutrients, both macro and micronutrients useful for plant growth [12]. The analysis of the composition of the vermicompost of Eisenia foetida showed that the vermicompost contains nutrients respectively $\mathrm{N}=$ $0.63 \%$, F $0.35 \%$, K $0.20 \%$, Ca $0.235, \mathrm{Mg} 0.26 \%$, Na $0.07 \%$, Zn $0.007 \%$ and Mn $0.003 \%$. Furthermore, the vermicompost fertilizer produced by earthworm species Lumbricus rubeltus is fed with water, spinach, and spinach waste containing nitrogen, phosphorus, and potassium nutrients [13]. These three elements are the main nutrients needed by plants to grow. Thus the treatment of vermicompost fertilizer can increase the diameter of the plant stem.
NPK fertilizer treatment can increase the diameter of tomato stems. The results of this study are in line with the results of research on other plants. NPK fertilizer treatment can increase the stem diameter of oil palm seedlings aged 8 months [14]. The treatment of NPK fertilizer with a dose of 22.5 grams per plot gave the highest yield of corn stem and was significantly different from the treatment of 0 grams per plot [15]. The pearl NPK fertilizer treatment affected the parameter of stem diameter of melon plants. The highest stem diameter was 11.86 $\mathrm{mm}$, obtained in the treatment of 5 grams NPK fertilizer [16]. The treatment of NPK fertilizer had a significant effect on the parameters of stem diameter and height of corn plants, where the best absorption of NPK fertilizer nutrients occurred in the fourth and fifth weeks after planting [17].

\section{Number of Compound Leaves}

The number of compound leaves of tomato plants differed according to the doses of vermicompost and NPK fertilizers applied to each experimental unit. The highest compound leaves were 52 in the combination treatment of $1.8 \mathrm{~kg}$ of vermicompost and 0.8 grams of NPK fertilizer. The lowest compound leaves was 41 , found in the control treatment.

Table 2. The data of Compound Leaves Number of Tomato Plant due to the treatment of vermicompost and NPK fertilizers.

\begin{tabular}{cccc}
\hline Combination & $\begin{array}{c}\text { Number of } \\
\text { Compound } \\
\text { Leaves }\end{array}$ & Combination & $\begin{array}{c}\text { Number of } \\
\text { Compound } \\
\text { Leaves }\end{array}$ \\
\hline A0K0 & 41 & A2K0 & 44 \\
A0K1 & 44 & A2K 1 & 45 \\
A0K2 & 45 & A2K2 & 47 \\
A0K3 & 47 & A2K3 & 52 \\
A0K4 & 46 & A2K4 & 50 \\
A1K0 & 42 & A3K0 & 42 \\
A1K 1 & 44 & A3K 1 & 43 \\
A1K2 & 46 & A3K2 & 45 \\
A1K3 & 49 & A3K3 & 47 \\
A1K4 & 49 & A3K4 & 48 \\
\hline
\end{tabular}

Analysis of diversity showed that different doses of vermicompost had a significant effect on the number of leaves of tomato plants. The treatment of NPK fertilizer significantly caused differences in the number of leaves of tomato plants. The combination of vermicompost and NPK didn't differ substantially in the number of tomato leaves. Vermicompost is produced with the support of earthworms. The increase in the number of compounds leaves due to the vermicompost fertilizer treatment is possible because the vermicompost contains organic matter that can improve the physical and chemical properties of the soil. The application of various organic materials such as chicken and cow excrements significantly affected the chemical properties of the entisol soil, the uptake of nitrogen, phosphorus, and potassium in plants, and the growth and production of sweet potatoes [18]. The provision of organic matter can increase nitrogen, phosphorus, and soil potassium [19]. The percentage of increase in the availability of 
these nutrients depends on the type of organic matter provided.

The treatment of NPK fertilizer can increase the number of leaves of tomato plants. The same results were found in other plants that the number of leaves and other growth parameters such as plant height, stem diameter, number of productive branches, leaf area index, and the yield gave a positive response [20]. N, P, and $\mathrm{K}$ are the main nutrients needed to support plant vegetative growth. Furthermore, it was found that pearl NPK fertilizer treatment could increase the number of sweet corn leaves. Treatment of 180 grams of pearl NPK fertilizer per plot gave an average yield of 15.65 leaves. Pearl NPK fertilizer treatment can also increase plant height, the length and diameter of cob, seed weight, and dry seed production of sweet corn [21]. The combination of NPK fertilizer and shoot source significantly impacted the number of leaves, plant height, length, width, and area of pineapple leaves [22]. NPK fertilizer treatment significantly increased the number of leaves, plant height, leaf area, number of fruits, and dry weight of green bean seeds [23].

\section{Leaf Strand Length}

The average length of the tomato leaf strand was different in each experimental unit. Generally, the length of tomato leaves increased in line with increasing doses of vermicompost and NPK fertilizers in each treatment combination. The highest leaf strand length was $130 \mathrm{~mm}$, while the lowest was $115 \mathrm{~mm}$. The data measurements of tomato leaf strand length due to the treatment of NPK fertilizer and vermicompost fertilizer are presented in Table 3.

Table 3. The Leaf Strand Length of Tomato Plant data due to the treatment of vermicompost and NPK fertilizer.

\begin{tabular}{cccc}
\hline Combination & $\begin{array}{c}\text { Leaf strand length } \\
(\mathrm{mm})\end{array}$ & Combination & $\begin{array}{c}\text { Leaf strand length } \\
(\mathrm{mm})\end{array}$ \\
\hline $\mathrm{A} 0 \mathrm{~K} 0$ & 115 & $\mathrm{~A} 2 \mathrm{~K}_{0}$ & 118 \\
$\mathrm{~A} 0 \mathrm{~K} 1$ & 117 & $\mathrm{~A} 2 \mathrm{~K}_{1}$ & 120 \\
$\mathrm{~A} 0 \mathrm{~K} 2$ & 120 & $\mathrm{~A} 2 \mathrm{~K}_{2}$ & 122 \\
$\mathrm{~A} 0 \mathrm{~K} 3$ & 125 & $\mathrm{~A} 2 \mathrm{~K} 3$ & 130 \\
$\mathrm{~A} 0 \mathrm{~K} 4$ & 123 & $\mathrm{~A} 2 \mathrm{~K} 4$ & 128 \\
$\mathrm{~A} 1 \mathrm{~K}_{0}$ & 116 & $\mathrm{~A} 3 \mathrm{~K}_{0}$ & 115 \\
$\mathrm{~A} 1 \mathrm{~K}_{1}$ & 118 & $\mathrm{~A} 3 \mathrm{~K}_{1}$ & 118 \\
$\mathrm{~A} 1 \mathrm{~K} 2$ & 122 & $\mathrm{~A} 3 \mathrm{~K}_{2}$ & 120 \\
$\mathrm{~A} 1 \mathrm{~K} 3$ & 126 & $\mathrm{~A} 3 \mathrm{~K} 3$ & 126 \\
$\mathrm{~A} 1 \mathrm{~K} 4$ & 125 & $\mathrm{~A} 3 \mathrm{~K} 4$ & 123 \\
\hline
\end{tabular}

The diversity analysis showed that the treatment of vermicompost could increase the length of the tomato leaf strand. NPK fertilizer treatment had a significant impact on increasing tomato leaf length. The combination of vermicompost fertilizer and NPK fertilizer did not significantly increase tomato leaf strand length. The increase in leaf strand length of tomato plants is caused by the improvement of the chemical and biological properties of the soil due to the vermicompost fertilizer treatment. The chemical and biological properties of vermicompost fertilizer were better than organic fertilizers produced from organic waste without earthworms [24]. The presence of earthworms involved in vermicompost production can increase beneficial microbes and nutrients in organic fertilizers. Furthermore, it was explained that the treatment of vermicompost and inorganic fertilizers could increase N's availability in the soil. The highest increase indicated by the treatment of vermicompost of 3 tons per hectare + urea $200 \mathrm{~kg}$ per ha, SP36 $=100 \mathrm{~kg} / \mathrm{ha}, \mathrm{KCl}=50$ $\mathrm{kg} / \mathrm{ha}$ i.e., $0.095 \%$. Increasing the uptake of $\mathrm{N}$ with the highest increase indicated by giving vermicompost 3 tons per hectare without inorganic fertilizer, namely $0.714 \mathrm{~g} / \mathrm{plant}$. They increased the total $\mathrm{N}$ of the soil with the highest increase indicated by giving vermicompost 3 tons per hectare + urea $200 \mathrm{~kg}$ per ha, SP36= $100 \mathrm{~kg} / \mathrm{ha}, \mathrm{KCL}=50 \mathrm{~kg} / \mathrm{ha}$, which was $0.30 \%$. The increase of $\mathrm{N}$ in plant tissue with the highest increase was indicated by the treatment of vermicompost of 3 tons per hectare without inorganic fertilizer, which was $0.30 \%$ [25]. Vermicompost has a very significant effect on several chemical and biological properties of the soil. The dose of 35.0 tons per hectare of vermicompost can increase $1.41 \%$ of $\mathrm{N}$ total, $5.56 \%$ availability of $\mathrm{P}$, $3.11 \%$ availability of soil organic C, $0.07 \%$ of soil $\mathrm{pH}$, and $12.89 \%$ of total microorganism population in the soil, as well as increasing $8.35 \%$ of the dry crown weight. A dose of 20.0 tons per hectare of vermicompost fertilizer could increase the number of 
leaves by $1.33 \%, 8.79 \%$ by the weight of the fresh crown and increase the yield of mustard greens [26].

NPK fertilizer treatment could increase the length of tomato plant leaves. Similar results were found in other plants. Treatment of NPK fertilizer could increase the leaf length, leaf strand, width and number of leaves, and stem height of land spinach. NPK fertilizer treatment of 1.5 grams per plant was the best treatment to support the growth of land spinach with the length, width, number of leaves respectively, $140 \mathrm{~mm}, 36 \mathrm{~mm}$, and 9 strands, and the highest stem height reached $=24 \mathrm{~cm}$ [27]. Treatment of NPK fertilizer can increase the length and width of the leaf strand, the number of leaves, and the height of the mustard greens. Treatment of 2 grams of NPK fertilizer gave the highest length, width, number of the leaves, and plant height compared to other doses of NPK fertilizer [28]. It was found that there was an increase in leaf length, number of leaves, plant height, and stem diameter of sweet corn plants due to NPK fertilizer treatment. A dose of 6 grams of NPK fertilizer is the best treatment to support the growth of sweet corn [29].

\section{Plant Height}

Plant height was measured from the base to the tip of the stem. The plant height varied in each experimental unit. Generally, plant height increased with increasing doses of vermicompost and NPK fertilizers. The highest plant height was $120 \mathrm{~cm}$ found in the treatment of 0.8 grams of NPK fertilizer and $1.8 \mathrm{~kg}$ of vermicompost fertilizer. The lowest plant height was $105 \mathrm{~cm}$ obtained in the control treatment. The data on tomato plant height due to different doses of NPK fertilizer and vermicompost fertilizer is presented in Table 4.

Table 4. The data of plant height due to the treatment of vermicompost and NPK fertilizer

\begin{tabular}{cccc}
\hline Combination & Plant height $(\mathrm{cm})$ & Combination & Plant height $(\mathrm{cm})$ \\
\hline $\mathrm{A}_{0} \mathrm{~K} 0$ & 105 & $\mathrm{~A} 2 \mathrm{~K}_{0}$ & 108 \\
$\mathrm{~A} 0 \mathrm{~K} 1$ & 107 & $\mathrm{~A} 2 \mathrm{~K}_{1}$ & 110 \\
$\mathrm{~A} 0 \mathrm{~K} 2$ & 110 & $\mathrm{~A} 2 \mathrm{~K}_{2}$ & 112 \\
$\mathrm{~A} 0 \mathrm{~K} 3$ & 115 & $\mathrm{~A} 2 \mathrm{~K}_{3}$ & 120 \\
$\mathrm{~A} 0 \mathrm{~K} 4$ & 113 & $\mathrm{~A} 2 \mathrm{~K} 4$ & 118 \\
$\mathrm{~A} 1 \mathrm{~K}_{0}$ & 106 & $\mathrm{~A} 3 \mathrm{~K}_{0}$ & 105 \\
$\mathrm{~A} 1 \mathrm{~K}_{1}$ & 108 & $\mathrm{~A} 3 \mathrm{~K}_{1}$ & 108 \\
$\mathrm{~A} 1 \mathrm{~K}_{2}$ & 112 & $\mathrm{~A} 3 \mathrm{~K}_{2}$ & 110 \\
$\mathrm{~A} 1 \mathrm{~K} 3$ & 116 & $\mathrm{~A} 3 \mathrm{~K}_{3}$ & 116 \\
$\mathrm{~A} 1 \mathrm{~K} 4$ & 115 & $\mathrm{~A} 3 \mathrm{~K} 4$ & 113 \\
\hline
\end{tabular}

The results of the variance analysis showed that both vermicompost and NPK fertilizer treatment had a significant effect on increasing tomato plant height. There was no increase in tomato plant height due to the combination of vermicompost and NPK fertilizers. Another study found that the application of vermicompost can increase plant height. The treatment of vermicompost had a significant effect on the height of mustard plants aged 9 to 29 days after planting. The highest plant height was $18.6 \mathrm{~cm}$, obtained by treating 60 grams of vermicompost. The vermicompost can also increase wet plant weight (10.3 grams), dry plant weight (1.3 grams), dry root weight (0.4 grams) [30]. The dose of vermicompost significantly affected plant height, number of leaves, and volume of lettuce canopy, with the best dose of 50 grams per polybag [31].

Application of NPK fertilizer can increase the height of tomato plants. The results of this study are in line with the results of research on other plants. The treatment of nitrogen and phosphorus fertilizers simultaneously on corn plants in regosol and latosol soils had a significant effect on plant growth, such as plant height, dry shoot weight, dry root, and total dry weight [32]. The treatment can increase the dry leaf and dry shoot weights of Shorea laevis. The greatest growth in plant height was obtained in the treatment of 2 grams of NPK fertilizer per plant [33]. The vermicompost and bio-activator application significantly affected plant height, the number of leaves, wet weight, and dry weight of mustard greens compared to with no treatment of vermicompost and bio-activator [34].

\section{CONCLUSION}

Based on the data obtained in the implementation of the study, it can be concluded: (1) the treatment of NPK fertilizer has a significant impact on the differences of stem diameter, number of compound leaves, leaf length, and height of tomato plants. NPK fertilizer treatment of 0.8 grams per plant resulted in the best result. (2) Treatment of vermicompost with different doses has a significant effect on stem diameter, the number of compound 
leaves, leaf length, and height of tomato plants. Treatment $1.8 \mathrm{~kg}$ of vermicompost resulted in the best. (3) The combination of vermicompost and NPK fertilizer has no significant effect on stem diameter, the number of compound leaves, leaf length, and height of tomato plants.

\section{REFERENCES}

[1] Wahyudi. (2012). Bertanam Tomat di Dalam Pot dan Kebun Mini. PT AgroMedia Pustaka. Jakarta.

[2] Rohman, A. (2020). Ensiklopedia Tomat, Deskripsi, Filosofi, Manfaat, Budidaya dan Pelung Bisnisnya. Karya Bakti Makmur Indonesia. Yogyakarta

[3] Wiryanta, T.W. (2008). Bertanam Tomat. PT. AgroMedia Pustaka. Jakarta Selatan

[4] Kusmuljono, B.S. (2009). Menciptakan Kesempatan Rakyat Berusaha. IPB Press. Bogor.

[5] Agustina, L. (2011). Teknologi Hijau dalam Pertanian Organik Menuju Pertanian Berlanjut. Universitas Brawijaya Press. Malang.

[6] Manahan, S., Idwar \& Wardati. (2016). Pengaruh Pupuk NPK dan Kascing terhadap Pertumbuhan kelapa Sawit (Elaeis Guineensis Jacq) fase main Nusery. JOM Faperta 3(2): 1 - 10.

[7] Dailami, A., Yetti, H. \& Yoseva, S. (2015). Pengaruh Pemberian Pupuk Kascing dan NPK terhadap Pertumbuhan dan Produksi Tanaman Jagung Manis (Zea mays var saccharata Sturt). JOM Faperta. 2(2): 1 - 12

[8] Tanggap Beberapa Dosis Pupuk Organik Kascing terhadap Pertumbuhan dan Hasil Tanaman Sawi (Brassica juncea L.) yang Berbeda Varietas. Agrologia. 7(2): 81 - 89

[9] Hidayatullah, W., Rosmawaty, T. \& Nur, M. (2020). Pengaruh pemberian Pupuk Kascing dan NPK Mutiara 16:16:16 terhadap Pertumbuhan dan Hasil Okra (Albelmoschus esculentus L. Moenc) serta Bawang Merah (Alium ascalonicum L.) dengan Sistem Tumpang Sari. Dinamika Pertanian. 36(1): 11 - 20

[10] Gomez K.A. \& A.A. Gomez. (1991).Prosedur Statistik Untuk penelitian Pertanian. Edisi Kedua Penerjemah: Endang Syamsudin dan Justika S. Baharsyah. UI Press. Jakarta.

[11] Teutenburg, H. and Shalabh(2009). Statistical Analysis of Designed Experiment. Third Edition. Springer. New York.

[12] Mulat, T. (2003). Membuat dan Memanfaatkan Kascing Pupuk Organik Berkualitas. AgroMedia Pustaka. Jakarta.

[13]Elfayetti, Sintong, M., Pinem, K. \& Primawati, L. (2017). Analisis Kadar Hara Pupuk Organik Kascing dari Limbah Kangkung dan Bayam. Jurnal Geografi. 9(1): 1 - 10
[14] Adnan, I.S., Utoyo, B. \& Kusumastuti, A. (2015). Pengaruh Pupuk NPK dan Pupuk Organik terhadap Pertumbuhan Bibit Kelapa Sawit (Elaeis guineensis Jacq) di Main Nursery. Agro Industri Perkebunan. 3(2): 69-81

[15] Irawan, S., Safruddin \&Marwani, R. (2019). Pengaruh Perlakuan Jarak Tanam dan Pupuk NPK terhadap Pertumbuhan dan Produksi Tanaman Jagung (Zea mays L) BERNAS Agricultural Research Journal. 15(1): 174 - 184

[16] Ayu, J., Sabli, E. \& Sulhaswardi(2017). Uji Pemberian Pupuk NPK Mutiara dan Pupuk Organik Cair Nasa terhadap Pertumbuhan dan Hasil Tanaman Melon (Cucumis melo L.) Jurnal Dinamika Pertanian. 33(1): 103 - 114.

[17]Febians, J.D. Hitijahubessy \& Siregar, A. (2016). Peranan Bahan Organik dan Pupuk Majemuk NPK dalam Menentukan Percepatan Pertumbuhan Tanaman Jagung (Zea mays saccharata L.) pada Tanah Inceptisol (Suatu kajian Analisis Pertumbuhan Tanaman). Jurnal Budidaya Pertanian. 12(1): 1 - 9

[18] Afandi, F.N., Siswanto, B \& Nuraini, Y. (2015). Pengaruh Pemberian Berbagai Jenis Bahan Organik terhadaap Sifat Kimia Tanah pada Pertumbuhan dan Produksi Tanaman Ubi Jalar di Entisol Ngrangkah Pawon Kediri. Jurnal Tanah dan Sumberdaya Lahan. 2(1): 237 - 244.

[19] Gusmini, Yulnafatmawita \&A.F. Daulay (2008). PengaruhPemberian BeberapaJenisBahan OrganikterhadapPeningkatan Kandungan Hara N, P dan Kultisol Kebun Percobaan Paperta Unad Padang. J.Solum,5(2):57-65.

[20] Firmansyah, I., Syakir, M. \& Lukman, L. (2017). Pengaruh Kombinasi Dosis Pupuk N, P dan K terhadap Pertumbuhan dan Hasil Tanaman Terung (Solanum melongena L.) J. Hort. 27(1): $69-78$.

[21] Assagaf, S.A.R. (2017). Pengaruh Pemberian Pupuk NPK Mutiara terhadap Pertumbuhan dan Produksi Tanaman Jagung. Jurnal Ilmiah Jurnal Agribisnis dan Perikanan. 10(1): 72 - 78.

[22] Cahyono, E, G., Ardian \& Silvina, F. (2014). Pengaruh Pemberian Beberapa Dosis Pupuk NPK terhadap Pertumbuhan Berbagai Sumber Tunas Tanaman Nanas (Annanas comosus L. merr) yang Ditanam Antara Tanaman Kelapa sawit Belum Menghasilkan di Lahan Gambut.Jom Faperta. 1(2): 1 - 13.

[23] Murdaningsih and Kramat, A.B. (2014). The Effect of Doses of NPK Fertilizer on The Growth and yield of Green Bean (Phaseolus radiates L.). Agrica. 7(1): $45-56$.

[24] Utama, D.S., Sudana, I.M. \& Kartini, N.L. (2017). Pengaruh Penggunaan Sampah Organik dan cacing tanah (Lumbricus rubellus) terhadap 
sifat kimia dan biologi pupuk kascing. J. Agric. Sci and Biotecnol. 6(1): 9 - 17.

[25] Khairani, I., Hartati, S. \& Mujiono(2010). Pengaruh Kascing dan Pupuk Anorganik terhadap ketersediaan nitrogen pada Alfisols dan serapannya oleh tanaman jagung manis (Zea mays L. saccharata). Ilmu Tanah dan Agroklimatologi. 7(20: 73 - 81.

[26] Sinda, K.M.N.K., Kartini, N. \& Atmaa, I.W.D. (2015). Pengaruh Dosis Pupuk Kascing terhadap Hasil Tanaman Sawi (Brassica juncea L.) Sifat Kimia dan Biologi pada Tanah Inceptisol Klungkung. E-Jurnal Agroteknologi Tropika. 4(3): $170-179$.

[27]Raksun, A., Mahrus \& Mertha, I.G. (2020). Vegetative Growthof Kale Land (Ipomoeareptanspoir.) Due to Different doses of NPK and BokashiFertilizer. Biologi Tropis. 20 (2): $305-313$.

[28] Raksun, A., Ilhamdi, M.L., Merta, I.W. \& Mertha, I.G. (2020). Vegetative Growthof Pakcoy(BrassicarapaL.) Due to Different DoseofBokashiand NPK Fertilizer, JurnalBiologi Tropis. 20 (3): 452 - 459.

[29] Raksun, A., Merta, I.W. Mertha, I.G., \& Ilhamdi, M.L. (2021). Response of Sweet Corn (Zea mays L. Sccharata) Growth on the Treatment of Organic and NPK Fertilizer. Biologi Tropis. 21 (1): $131-139$.

[30] Pratama, T.Y., Nurmayulis \& Rohmawati, I. (2018). Tanggapan Beberapa Dosis Pupuk Organik Kascing terhadap Pertumbuhan dan Hasil Tanaman Sawi (Brassica juncea L) yang Berbeda Varietas. Agrologia. 7(2):81 - 89.

[31] Dosem, I.R., Astuti, Y.T.M. \& Santosa, T.N.B. (2018). Pengaruh Dosis Pupuk Kascing dan Volume Penyiraman terhadap Hasil Tanaman Selada (Lactuca sativa). Jurnal Agromast. 3(1): 1 $-11$.

[32]Fahmi, A., Syamsudin, Utami, S.N. \& Radjagukguk, B. (2010). Pengaruh Interaksi Hara Nitrogen dan Fosfor terhadap Pertumbuhan Tanaman Jagung (Zea mays L.) pada Tanah Regosol dan Latosol. Berita Biologi. 10(3): 297 $-304$.

[33] Handayani, R. and Apriani, H. (2020). Effect of NPK Fertilizer and Planting Media on The growth and Production of Shorea laevis Ridl. Jurnal Penelitian Ekosistem Dipterokarpa. 6(2): $107-116$.

[34] Wahyudin, S. \& Irawan, A.W. (2019). Pengaruh Dosis Kascing dan Bioaktivator terhadap
Pertumbuhan dan Hasil Tanaman Sawi (Bassica juncea L.) yang Dibudidayakan Secara Organik. Jurnal Kultivasi .18(2): 899-902. 